\title{
Public policies of food and nutrition in Brazil: From Lula to Temer
}

\author{
Políticas públicas de alimentação e nutrição \\ do Brasil: de Lula a Temer
}

\author{
Francisco de Assis Guedes de VASCONCELOS1 (iD) 0000-0002-6162-8067 \\ Mick Lennon MACHADO² (ID) 0000-0001-7550-1692 \\ Maria Angélica Tavares de MEDEIROS 3 (ID) 0000-0002-8982-7084 \\ José Anael NEVES 3 iD 0000-0003-4139-4352 \\ Elisabetta RECINE4 ${ }^{4}$ (D) 0000-0002-5953-7094 \\ Elaine Martins PASQUIM ${ }^{4}$ iD 0000-0002-0377-981X
}

A B S T R A C T

\section{Objective}

To analyze public policies on food and nutrition in Brazil, with emphasis on the last fifteen years (2003-2018).

\section{Methods}

Historical-documentary analysis based on a bibliographical survey on indexed bases and exploratory visits to websites of government agencies.

\section{Results}

The scientific and governmental findings were organized according to the Lula, Dilma and Temer governments. They explore the development of several public policies and welfare programs in food and nutrition, focusing mainly on Brazilian Hunger Eradication Program, Assistance for Needy Families Program, National Policy on

${ }^{1}$ Universidade Federal de Santa Catarina, Centro de Ciências da Saúde, Departamento de Nutrição. Campus Universitário, s/n., Trindade, 88040-9000, Florianópolis, SC, Brasil. Correspondence to: FAG VASCONCELOS. E-mail: $<$ f.vasconcelos@ufsc.br>.

2 Universidade Federal de Santa Catarina, Centro de Ciências da Saúde, Programa de Pós-Graduação em Nutrição. Florianópolis, SC, Brasil.

3 Universidade Federal de São Paulo, Departamento de Políticas Públicas e Saúde Coletiva, Programa de Pós-Graduação em Alimentos, Nutrição e Saúde. Santos, SP, Brasil.

${ }^{4}$ Universidade de Brasília, Faculdade de Ciências da Saúde, Departamento de Nutrição. Brasília, DF, Brasil.

How to cite this article

Vasconcelos FAG, Machado ML, Medeiros MAT, Neves JA, Recine E, Pasquim EM. Public policies of food and nutrition in Brazil: From Lula to Temer. Rev Nutr. 2019;32:e180161. http://dx.doi.org/10.1590/1678-9865201932e180161 
Food and Nutrition Security, Food Acquisition Program, National School Nutrition Program, National Food and Nutrition Security Policy, National Food and Nutrition Surveillance System and Brazilian Misery Eradication Program. The centrality of the idea of the fight against hunger and misery in public policies during Lula's first and second terms and Dilma's first term stand out. Dilma's second term is marked by the focus on healthy eating, as well as presenting the first signs of fragilization of public policies on food and nutrition. Currently, the Temer government is characterized by processes of institutional and programmatic rupture, budget cuts and setbacks in acquired rights. There is evidence of the need to activate national and international instruments to enforce the human right to adequate food and consequent strengthening of public policies on food and nutrition.

\section{Conclusion}

This period presents an expansion and qualification of public policies on food and nutrition, mainly in the Lula and Dilma administration, with setbacks in the Temer administration, in which continuous budget cuts weaken social, hunger reduction, poverty reduction and food and nutrition security policies.

Keywords: Food and Nutrition Security. Nutrition Policy. Nutrition Programs and Policies. Public policy.

\section{RE S U M O}

\section{Objetivo}

Realizar análise da política pública de alimentação e nutrição no Brasil, com ênfase nos últimos quinze anos (2003-2018).

\section{Métodos}

Análise histórico-documental, realizada a partir de levantamento bibliográfico em bases indexadas e visitas exploratórias a sítios eletrônicos de órgãos governamentais.

\section{Resultados}

Os achados científicos e governamentais foram organizados de acordo com os governos Lula, Dilma e Temer. Exploram o desenvolvimento de diversas políticas públicas e programas em alimentação e nutrição, com enfoque principalmente no Fome Zero, Programa Bolsa Família, Política Nacional de Segurança Alimentar e Nutricional, Programa de Aquisição de Alimentos, Programa Nacional de Alimentação Escolar, Política Nacional de Alimentação e Nutrição, Sistema Nacional de Vigilância Alimentar e Nutricional e Programa Brasil sem Miséria. Destaca-se a centralidade do discurso do combate à fome e à miséria nas políticas públicas durante os governos Lula e primeiro governo Dilma. O segundo governo Dilma é marcado pelo enfoque na alimentação saudável, além de apresentar um início de fragilização das políticas públicas em alimentação e nutrição. O governo Temer se caracteriza por processos de ruptura institucionais e programáticas, cortes orçamentários e retrocessos em direitos conquistados. Evidencia-se a necessidade de instrumentos nacionais e internacionais de exigibilidade do direito humano à alimentação adequada.

\section{Conclusão}

O período analisado apresenta uma expansão e qualificação das políticas públicas em alimentação e nutrição, principalmente nos governos Lula e Dilma, com retrocessos no governo Temer, em que cortes orçamentários contínuos fragilizam as políticas sociais, de redução da fome, da miséria, da pobreza e da promoção da segurança alimentar e nutricional.

Palavras-chave: Segurança Alimentar e Nutricional. Política Nutricional. Programas e Politicas de Nutrição e Alimentação. Política Pública.

\section{N TRODUCTION}

In Brazil, the path of institutionalization of food and nutrition public policies, which began in the mid-1930s, converges with the history of the emergence of the profession of nutritionist, which completes 80 years of existence in 2019 [1,2].

Throughout this trajectory it becomes relevant to recognize the profound economic, political, social and cultural changes that have occurred both within the context of Brazilian society and within the framework of human society. These changes include those related to the nutritional epidemiological profile, which, in the 1930s, consisted mainly of diseases associated with nutritional deficiencies. From this period to the present day, non-communicable chronic nutritional diseases have 
been superimposed, implying the need to construct new paradigms and new forms of intervention in food and nutrition $[1,3]$.

In the last 15 years, several studies have been identified in the field of public policies on food and nutrition in Brazil, some of which have addressed the issue in a comprehensive way [4-6], while others have focused on the analysis of specific programs, such as the Programa Nacional de Alimentação Escolar (PNAE, National School Nutrition Program) [7-10]; the Programa Bolsa Família (PBF, Family Grant Program) [11-14]; the Programa de Aquisição de Alimentos (PAA, Food Acquisition Program) $[15,16]$; the government-backed economy restaurants program $[17,18]$; and the Sistema Nacional de Segurança Alimentar e Nutricional (SISAN, National System of Food and Nutrition Security) $[19,20]$.

In the present article, it is assumed that, since 2003, a process of redefinition of the strategies of planning, management and execution of its actions and programs has taken place in the field of public policies for food and nutrition. Thus, in order to foster a change in the development model beyond the focus of economic growth, it was sought a process that should be based on the effective intersectoriality between the government agencies of the different governmental spheres involved, as well as on the effective participation of the organized civil society - the main mechanism of social control of this policy - and, consequently, of promoting and guaranteeing the human right to adequate food for all Brazilians $[6,20]$.

In this sense, the objective of this article is to perform a historical-documentary analysis of the public policies of food and nutrition in Brazil, focused in the last 15 years (2003-2018).

\section{METHODS}

This article is characterized as a historical-documentary analysis that seeks to synthesize the trajectory of the public policies for food and nutrition in Brazil over the last 15 years.

To obtain data, information and documents on the trajectory of the Brazilian food and nutrition policies from 2003 to 2018, exploratory visits were made to the websites of the government agencies involved, such as: (1) Conselho Nacional de Segurança Alimentar e Nutricional (CONSEA, National Council of Food and Nutrition Security) (http://www4.planalto.gov.br/consea); (2) Ministério da Saúde - Coordenação-Geral de Alimentação e Nutrição (CGAN, Ministry of Health - General Coordination of Food and Nutrition) (http://dab.saude.gov.br/portaldab/cgan.php); (3) Ministry of Social Development (http://mds.gov.br/assuntos/bolsa-familia); and (4) the Ministry of Education (http://www.fnde.gov.br/programas/pnae).

In an attempt to capture scientific articles on the subject which were published in the last 15 years, a bibliographic survey was carried out at the Scientific Electronic Library Online (SciELO), the National Library of Medicine (PubMed) and the Web of Science databases, using the terms: "public policy"; "social policy"; "food and nutrition programs"; "nutrition programs"; "food and nutrition"; "nutrition"; "hunger"; "Food and nutrition security"; "Family Grant Program"; "Programa Fome Zero" (Hunger Eradication Program); "National School Nutrition Program" and its acronym PNAE; "Government-backed Economy Restaurants"; "Food Acquisition Program" and its acronym PAA, all terms being researched both in Portuguese and with their respective correspondents in the English language as well. The inclusion criteria involved the original articles whose contents and objectives contained analyzes of the various government policies in food and nutrition in the previously defined temporal cuts. The selected articles covered the most diverse methodologies in order to expand the possibilities of identified actions. The interpretation of the findings suggested that the treatment of data and information should be organized into three macro indicators or periods: the Lula government 
(2003-2010), the Dilma government (2011-2016), and the Temer government (2016-July, 2018). The categorization sought to highlight the procedural, historical and social relationship of food and nutrition policies and programs.

\section{Lula Era (2003-2010): Hunger eradication (Fome Zero) and assistance for needy families (Bolsa Familia) programs}

The Lula government started in an atmosphere of euphoria caused by the publicity of the actions of the Programa Fome Zero (PFZ, Hunger Eradication Program), which aimed to eradicate hunger and implement a national policy of Food and Nutrition Security (FNS) in Brazil, through structural policies, both specific and local [21].

In the first year of the government, conditional income transfer programs were unified with the creation of the PBF. Short, medium and long-term objectives have been designed, among them: to promote access to the network of public services, especially the ones related to health, education and social assistance; combat hunger and poverty; promote FNS policies; contribute to the full exercise of citizenship and the sustained emancipation of families who are most vulnerable to hunger; and promote the intersectoriality, complementarity and synergy of the social actions of the public administration. Thus, the PBF provided for the transfer of monetary resources to families living in poverty and extreme poverty layers, the access to health services and education in the form of conditionalities, as well as intersectoral actions and complementary programs.

The PBF has become the world's largest income transfer program, absorbing most of the monetary resources earmarked for the Política Nacional de Segurança Alimentar e Nutrição (PNSAN, National Policy on Food and Nutrition Security) [11]. At the end of 2010, the PBF had benefited 12.8 million Brazilian families with an income transfer of BRL14.4 billion per year (Table 1).

Table 1. Number of families benefited and accumulated annual budget value of the Programa Bolsa Família (PBF, Family Grant Program) in Brazil, 2004 to 2018.

\begin{tabular}{lcc}
\hline Year & Number of families & Yearly budget (BRL) \\
\hline 2004 & $6,571.839$ & $3,791,785,038.00$ \\
2005 & $8,700.445$ & $5,691,667,041.00$ \\
2006 & $10,965.810$ & $7,524,661,322.00$ \\
2007 & $11,043.076$ & $8,965,499,608.00$ \\
2008 & $10,557.996$ & $10,606,500,193.00$ \\
2009 & $12,370.915$ & $12,454,702,501.00$ \\
2010 & $12,778.220$ & $14,372,702,865.00$ \\
2011 & $13,361.495$ & $17,364,277,909.00$ \\
2012 & $13,902.155$ & $21,156,774,695.00$ \\
2013 & $14,086.199$ & $24,890,107,091.00$ \\
2014 & $14,003.441$ & $27,187,295,233.00$ \\
2015 & $13,936.791$ & $27,650,301,339.00$ \\
2016 & $13,569.576$ & $28,506,185,141.00$ \\
2017 & $13,828.609$ & $29,046,112,934.00$ \\
Until June, 2018 & $13,736.341$ & $14,881,878,458.00$ \\
\hline
\end{tabular}

Note: BRL: Brazilian currency (Reais: $R \$$ ).

Based on data from the Ministry of Social Development (Brazil) [22]. 
Fifteen years after its implementation began, there is evidence of the impact of the PBF on reducing both income inequality and poverty indexes [23], minimizing poverty and hunger in Brazil [24]; the increased use of health services by beneficiary children [25] and decreased post-neonatal infant mortality [26]. On the other hand, when it comes to studies of the impact of PBF on nutritional status, food consumption and FNS, the results are still inconclusive $[11,14,27,28]$.

In 2003, the CONSEA was reconstituted as an advisory agency to the President, with $1 / 3$ of its board composed of government members and $2 / 3$ composed of civil society members. At the time, its mission was to broaden the debate on the issue of FNS, and to convene the // Conferência Nacional de SAN (II Food and Nutrition Security National Conference), placing social participation at the center of the structural changes related to the FNS agenda [29]. The II Food and Nutrition Security National Conference, held in 2004, deliberated on the proposal of the Lei Orgânica de Segurança Alimentar e Nutricional (LOSAN, Organic Law of Food and Nutrition Security) [30].

Sanctioned in 2006, the LOSAN instituted the SISAN, which was formed by the following three levels of government: Food and Nutrition Security Conference, CONSEA, Câmara Intersetorial de Segurança Alimentar e Nutricional (CAISAN, Intersectorial Chamber for Food and Nutrition Security), FNS agencies and entities, and private, non-profit institutions [31].

The PAA, created in 2003, has innovated by being conceived as an instrument of agricultural policy and access to adequate and healthy food [20]. It is a program of institutional purchase of food from family farmers, which creates short supply chains, bringing together producers and consumers, as a way to strengthen FNS policies and to increase the income of producers [32]. The Program also encourages pesticide-free food production; improving family nutrition and strengthening other direct food purchase programs, including the PNAE.

The III Food and Nutrition Security National Conference was held in 2007, and aimed to contribute to the construction of SISAN, proposing guidelines, axes and priorities of the Food and Nutrition Security Policy and National Plan, and incorporating food sovereignty as a strategic element of this public policy [33].

In 2010, through Constitutional Amendment No.64, food was included among social rights in Brazil, set forth in Article 6 of the Federal Constitution of 1988. That same year, the Decree No.7.272/2010, which regulated LOSAN, the PNSAN and established the parameters for elaboration of the National Plan of Food and Nutrition Security was published [19].

During the Lula administration, there were some developments in the first edition of the Politica Nacional de Alimentação e Nutrição (PNAN, National Food and Nutrition Security Policy), published in 1999. Recine \& Vasconcellos [5] highlighted important events of this period, namely: the configuration and development of food and nutrition surveillance, the regular production of information on nutritional status through population-based research, building an agenda of healthy food promotion, and training of human resources.

Monitoring of food and nutritional issues in Brazil gained strength based on population-based surveys, including the Pesquisa Nacional de Demografia e Saúde (PNDS, National Demographic and Health Survey) in 2006, which included the first national study on the prevalence of anemia and hypovitaminosis A, in addition to the Pesquisas de Orçamento Familiar (POF, Family Budget Surveys) for the years 2002-2003 and 2008-2009 [5].

Regarding the promotion of healthy eating habits, the agenda was qualified with the publication of the first edition of the Food Guide for the Brazilian Population (2006), assuming that 
healthy food should be based on food practices that have cultural and social meaning, therefore, based on the consumption of food and not of nutrients [34].

Another important event was the creation of the Núcleos de Apoio ao Programa Saúde na Familia (NASF, Family Health Program Support Centers), with the objective of qualifying and expanding the breadth, scope and resolution of basic health care actions, through the insertion of different professionals in the family health teams, among them the nutritionist [35]. Vasconcelos et al. [36] identified an increase in the number of nutritionists in Basic Health-Care clinics after the creation of NASF, although this number remains below health needs. Also, the insertion of the nutritionist into the NASF was an important step in boosting the organization of nutritional care in health services [35].

The Lula Government was also the background of changes in the legal frameworks of the PNAE, following the approval of Law No.11.947/2009 and Resolution No.38/2009 of the Fundo Nacional de Desenvolvimento da Educação (FNDE, National Fund for Education Development) [37]. Among these modifications, three guidelines stand out: the use of adequate and healthy eating habits, including the use of varied and safe foods, respecting the local food culture, traditions and healthy eating habits; the inclusion of food and nutrition education in the school curriculum; and the requirement of acquiring diversified food, produced locally and preferably by family agriculture, using at least 30\% of the FNDE's resources for this purpose, prioritizing the native production of indigenous communities, quilombolas, agrarian reform settlements, and organic and agroecological foods [37]. Table 2 contains information on the performance of the PNAE throughout the Lula government, in relation to the number of students benefited and the amount of financial resources spent.

Table 2. Number of participating students and yearly budget of the Programa Nacional de Alimentação Escolar (PNAE, National School Nutrition Program). Brazil, 2003 to 2018.

\begin{tabular}{lcc}
\hline Year & Participating students (in millions) & Yearly budget (in billions of BRL) \\
\hline 2003 & 37.3 & 0.954 \\
2004 & 37.8 & 1.025 \\
2005 & 36.4 & 1.266 \\
2006 & 36.3 & 1.500 \\
2007 & 35.7 & 1.520 \\
2008 & 34.6 & 1.490 \\
2009 & 47.0 & 2.013 \\
2010 & 45.6 & 3.034 \\
2011 & 44.4 & 3.051 \\
2012 & 43.1 & 3.306 \\
2013 & 43.3 & 3.542 \\
2014 & 42.2 & 3.693 \\
2015 & 41.5 & 3.759 \\
2016 & 40.3 & 3.400 \\
2017 & 40.6 & 3.900 \\
Until June, 2018 & 40.8 & 1.800 \\
\hline
\end{tabular}

Note: BRL: Brazilian currency (Reais: R\$).

Based on data from the Ministry of Social Development, National Fund for Education Development (Brazil) [38]. 


\section{Dilma Era (2011-2016): Brazilian Misery Eradication Program (Programa Brasil Sem Miséria) and other actions}

At first glance, it can be said that if the focal point of the Lula administration's politicalideological discourse was the fight against hunger, in the first Dilma term, the discourse went to combat poverty or extreme poverty, symbolized by the launch of the Programa Brasil Sem Miséria (PBSM, Brazilian Misery Eradication Program). The fight against hunger and misery were the central issues that marked social policies and, in particular, food and nutrition policies, and can be understood as the main tools used to generate consensus, legitimacy and hegemony of the two Brazilian Labor Party administrations [39].

The PBSM was based on a daring goal of eradicating extreme poverty in the country before 2014, targeting 16 million Brazilians and structuring on three axes: (1) productive inclusion (rural and urban); (2) income guarantee for social protection; and (3) access to public services for social protection and promotion [40-42].

In the specific field of public policies on food and nutrition, the productive inclusion axis in the rural area sought to articulate strategic actions aimed at accessing water for production and consumption, supporting productive structuring and marketing of food. In 2011, 82,000 extremely poor family farmers were included in the PAA, which has applied more than BRL5 billion in purchases of food from family agriculture since its creation until 2013, and has purchased about 4 million metric tons of food so far. The Rural Productive Activities Promotion Program, until October 2014, had transferred funds to more than 123 thousand families of small farmers [40].

In the income guarantee axis, the PBF underwent operational and financial changes that resulted in a readjustment of the benefit value, with greater corrections for those in greater vulnerability, besides the creation of new benefits and increase in the limit of benefits, leading to the inclusion of 1,3 million children [40].

In the area of access to public services, the launch of the Affectionate Brazil Program in $2012[40,41]$ stands out, focusing on families in extreme poverty, with children up to six years old, beneficiaries of the PBF, who started receiving the Benefit for Overcoming Extreme Poverty in Early Childhood, and in February 2013, the complementation of income began to cover all beneficiaries of the PBF. In the specific field of food and nutrition, the Affectionate Brazil Program also consisted of increasing the number of places in day-care centers, improvements in PNAE, supplementation of vitamin $A$, iron and other vitamins and minerals $[40,41]$.

According to the MDS assessment, the PBSM had met its goal of ending misery as early as March 2013, when 22 million Brazilians had crossed the line and left extreme poverty [42].

Other relevant strategies of the social policy of food and nutrition of the first term of the Dilma administration deserve to be highlighted: the dissemination of the National Plan for Food and Nutrition Security (2012/2015) [43]; the update of the PNAN [44]; the publishing of the Reference Framework of Food and Nutrition Education (FNE) for Public Policies [45]; the institution of the National Strategy for Promotion of Breastfeeding and Healthy Supplementary Feeding in Sistema Único de Saúde (SUS, Unified Public Health System) [46]; and the launch of the new edition of the Food Guide for the Brazilian Population [47]. 
The second term of the Dilma Rousseff administration (2015-2016) was marked by a strong recession and rising unemployment rates, due to a global economic crisis [48]. This crisis was intensified by a political crisis that resulted in the impeachment of the President in August, 2016 [49]. At this juncture, from 2015 onwards, an attempt was made to deal with these crises, which resulted in a cut of BRL 70 billion in government spending, partially applied to social programs and policies [50].

In 2015, there was a reduction of $6 \%$ compared to 2014 in the government spending with the PAA, which in 2016 accumulated losses of more than 30\% compared to 2014 [51]. According to Table 1, in 2015 the number of families benefited by the PBF was lower than in 2014, a reduction that was repeated in 2016, although in this year the budget for the program was increased. In relation to the PNAE, Table 2 shows that in 2016 there was a 9\% reduction in the budget directed from the federal administration to states and municipalities, in relation to the previous year.

In response to the progressive increase in chronic noncommunicable diseases, the second term of the Dilma Rousseff administration emphasized the promotion of healthy eating habits. In 2015, the National Pact for Healthy Eating was established to increase the supply, availability and consumption of healthy foods and to combat excess weight, obesity and diseases rooted in a poor diet [52]. In 2016, the II Food and Nutrition Security National Plan was elaborated, which reinforced the importance of facing the growing issue of excess weight and of NCD, as well as promoting the provision of healthy food for the entire population [53].

\section{Temer Era (May, 2016- July, 2018)}

On May 12, 2016, the change of the federal executive command led to institutional and programmatic ruptures, and to budget cuts that directly impacted on food and nutrition policies, indicating paradigm shifts and setbacks in the principles and acquired rights.

One of the first measures taken by the Temer administration in agrarian and rural areas was the extinction of the Ministério do Desenvolvimento Agrário (MDA, Ministry of Agrarian Development), which added to the threat of approving Bill 6,299/2002, which flexibilizes the legislation on pesticides [54]. Also noteworthy is the approval of the new fiscal regime established by Constitutional Amendment No.95, which establishes that the actual values of health and education government expenditure floors are frozen for two decades [55]. resources from the PBF and the Estratégia Saúde da Família (ESF, Family Health Strategy), continued austerity and the accompanying reductions in coverage of both programs will lead to an $8.6 \%$ increase in child mortality by 2030 [56]. If policies were maintained in the previous parameters, under-5 mortality rates for diarrheal diseases and malnutrition would be $39.3 \%$ and $35.8 \%$ lower in 2030 [13].

According to the Instituto de Pesquisa Econômica Aplicada (IPEA, Institute for Applied Economic Research) [57], fiscal adjustment will not allow expansion of coverage or creation of new initiatives by the Ministry of Social Development, since budget losses tend to reach 54\% in 2036. The budget cut in the Food and Nutrition Security of the Pluriannual Plan (PPA) in 2017 compared to 2014 was around 76\%, while the external debt repayment budget increased by $344 \%$ [58]. The weakening of the National Food and Nutrition Security Plan is shown in Table 3. 
Table 3. Percentage of budget reduction of programs and goals of the National Food and Nutrition Security Plan. Brazil, 2014-2018.

\begin{tabular}{|c|c|c|c|}
\hline Program/Goals & LOA (2014) & LOA (2018) & Reduction (\%) \\
\hline $\begin{array}{l}\text { Distribution of food to traditional and specific population groups (food } \\
\text { basket) }\end{array}$ & BRL82 million & BRL27.4 million & 67 \\
\hline Ecological grant program & BRL106.2 million & - & 100 \\
\hline $\begin{array}{l}\text { Support for the sustainable development of quilombola communities, } \\
\text { indigenous peoples and traditional peoples and communities }\end{array}$ & BRL6 million & - & 100 \\
\hline Technical Assistance and Rural Extension (ATER) & BRL630 million & BRL185.4 million & 71 \\
\hline $\begin{array}{l}\text { Technical Assistance and Rural Extension for settled and extractive families } \\
\text { (ATES) }\end{array}$ & BRL357 million & BRL19.7 million & 94 \\
\hline Productive inclusion of women & BRL32.5 million & BRL3.6 million & 89 \\
\hline Food Acquisition Program (PAA) & BRL1.3 billion & BRL431 million & 67 \\
\hline "Water for All" Program (Cisterns) & BRL248.8 million & BRL40.8 million & 94 \\
\hline International Humanitarian Cooperation & BRL38.4 million & BRL6.3 million & 84 \\
\hline
\end{tabular}

Note: LOA: Annual Budget Law; BRL: Brazilian currency (Reais: R\$)

Based on data from the National Council on Food and Nutrition Security (Brazil) [59].

In May 2018, the proposal for Provisional Measures to make feasible an agreement made with the cargo transport movement resulted in the cancellation of budget programs, which had already undergone previous cuts, such as agrarian reform and technical assistance, and rural extension programs [8], focused on preserving biodiversity, fighting gender violence, providing basic sanitation services, sustainable development, housing, as well as several programs of Health [13] and Education [60].

These facts confirm worrisome projections of a return to food insecurity, hunger and poverty in the country. It is necessary to point out that the State can be held liable for noncompliance with its obligations to social policies, especially Food and Nutrition Security, considering besides the constitution, the San Diego Protocol, signed by Brazil in 1996, in which the State cannot retreat in relation to the economic, social and cultural rights, Law No.11.346/2006 and Decree No.7.272/2010, which establishes the Sistema Nacional de Segurança Alimentar e Nutricional (SISAN, National System of Food and Nutrition Security).

Given this framework, the need to activate national and international instruments to enforce the human right to adequate food is reinforced. The mobilization of agencies responsible for national and international rights is one of the feasible ways to control and reverse the suppression of rights.

\section{CONCLUSION}

The analyzed period regarding the policies of food and nutrition in Brazil revealed three major cycles in its historical construction, in which changes in ideas, values and interests were identified. In the Lula administration, legal frameworks with implementation and valuing of food and nutrition security to reduce hunger were created, although there were contradictions such as the incentive to industrial agriculture based on large properties. The Dilma administration can be subdivided in two moments, initially with the idea of eradication of misery and extreme poverty, followed by a period of recession, in which an austerity policy is initiated, associated to the promotion of healthy eating 
habits in the face of aggravation of chronic diseases noncommunicable diseases. Finally, the austerity policy intensifies with the Temer administration, where continued budget cuts weaken social, hunger reduction, poverty reduction and food and nutrition security policies.

\section{CONTRIBUTORS}

FAG VASCONCELOS participated in the conception, development, revision and approval of the final version of the article. All other authors participated in the development, revision and approval of the final version of the article.

\section{REFERENCES}

1. Vasconcelos FAG. Combate à fome no Brasil: uma análise histórica de Vargas a Lula. Rev Nutr. 2005;18(4):439-57. http://dx.doi.org/10.1590/S1415-52732005000400001

2. Domene SMA, Ota RRL, Nilson EAF, Ollertz MIS, Watanabe TT, Gallo PR. Experiências de políticas em alimentação e nutrição. Estud Av. 2007;21(60):161-78.

3. Vasconcelos FAG. A ciência da nutrição em trânsito: da nutrição e dietética à nutrigenômica. Rev Nutr. 2010;23(6):935-45. http://dx.doi.org/10.1590/\$1415-52732010000600001

4. Alves KPS, Jaime PC. A política nacional de alimentação e nutrição e seu diálogo com a política nacional de segurança alimentar e nutricional. Ciênc Saúde Coletiva. 2014;19(11):4331-40. http://dx.doi.org/10.15 90/1413-812320141911.08072014

5. Recine $E$, Vasconcellos $A B$. Políticas nacionais e o campo da alimentação e nutrição em saúde coletiva: cenário atual. Ciênc Saúde Coletiva. 2011;16(1):73-9. http://dx.doi.org/10.1590/S1413-81232011000100011

6. Rigon SA, Schmidt ST, Bógus CM. Desafios da nutrição no Sistema Único de Saúde para construção da interface entre a saúde e a segurança alimentar e nutricional. Cad Saúde Pública. 2016;32(3):e00164514. http://dx.doi.org/10.1590/0102-311X00164514

7. Recine E. O Programa Nacional de Alimentação Escolar: o mundo se inspira, seremos capazes de manter os avanços? Cad Saúde Pública. 2017;33(12):e00087617. http://dx.doi.org/10.1590/0102-311x00087617

8. Schwartzman F, Mora CAR, Bogus CM, Villar BS. Antecedentes e elementos da vinculação do programa de alimentação escolar do Brasil com a agricultura familiar. Cad Saúde Pública. 2017;33(12):e00087617. http:// dx.doi.org/10.1590/0102-311x00099816

9. Silva EO, Amparo-Santos L, Soares MD. Alimentação escolar e constituição de identidades dos escolares: da merenda para pobres ao direito à alimentação. Cad Saúde Pública. 2018;34(4):e00142617. http://dx.doi. org/10.1590/0102-311x00142617

10. Gabriel CG, Calvo MCM, Vasconcelos FAG, Lacerda JT, Freitas SFT, Schmitz BAS. Avaliação da gestão municipal do Programa Nacional de Alimentação Escolar nos maiores municípios de Santa Catarina, Brasil. Cad Saúde Pública. 2014;30(9):2017-23. http://dx.doi.org/10.1590/0102-311XER00112813

11. Cotta RM, Machado JC. The Bolsa Família cash transfer program and food and nutrition security in Brazil: A critical review of the literature. Rev Panam Salud Publica. 2013;33(1):54-60.

12. Lima FE, Rabito El, Dias MR. Nutritional status of the adult population in the Bolsa Familia Program in Curitiba, State of Parana, Brazil. Rev Bras Epidemiol. 2011;14(2):198-206.

13. Trevisani JJD, Burlandy L, Jaime PC. Fluxos decisórios na formulação das condicionalidades de saúde do programa bolsa família. Saúde Soc. 2012;21(2):492-509. http://dx.doi.org/10.1590/S0104-129020120002 00021

14. Wolf MR, Barros Filho Ade A. Nutritional status of beneficiaries of the Bolsa Família Program in Brazil: A systematic review.Ciênc Saúde Coletiva. 2014;19(5):1331-8. http://dx.doi.org/10.1590/1413-812320141 95.05052013

15. Assis SCR, Priore SE, Franceschini SCC. Impacto do programa de aquisição de alimentos na segurança alimentar e nutricional dos agricultores. Ciênc Saúde Coletiva. 2017;22(2):617-26. http://dx.doi.org/10.1590/1413-81 232017222.02292015 
16. Batista LMG, Ribeiro SMR, Santos RHS, Araújo RMA, Ribeiro AQ, Priore SE, et al. Percepção de agricultores familiares do Programa de Aquisição de Alimentos (PAA) sobre o significado de fazer parte do PAA e a sua compreensão sobre conceitos relacionados à alimentação, nutrição e saúde. Saúde Soc. 2016;25(2):494-504. http://dx.doi.org/10.1590/S0104-12902016150258

17. Godoy KC, Sávio KEO, Akutsu RC, Gubert MB, Botelho RBA. Perfil e situação de insegurança alimentar dos usuários dos restaurantes populares no Brasil. Cad Saúde Pública. 2014;30(6):1239-49. http://dx.doi. org/10.1590/0102-311X00084013

18. Sobrinho FM, Silva YC, Abreu MNS, Pereira SCL, Dias Júnior CS. Fatores determinantes da insegurança alimentar e nutricional: estudo realizado em Restaurantes Populares de Belo Horizonte, Minas Gerais, Brasil. Ciênc Saúde Coletiva. 2014;19(5):1601-11. http://dx.doi.org/10.1590/1413-81232014195.18022013

19. Machado ML, Gabriel CG, Soar C, Mamed GR, Machado PMO, Lacerda JT, et al. Adequação normativa dos planos estaduais de segurança alimentar e nutricional no Brasil. Cad Saúde Pública. 2018;34(1):e00206716. http://dx.doi.org/10.1590/0102-311X00206716

20. Burlandy L. A construção da política de segurança alimentar e nutricional no Brasil: estratégias e desafios para a promoção da intersetorialidade no âmbito federal de governo. Ciênc Saúde Coletiva. 2009;14(3):851-60. http://dx.doi.org/10.1590/S1413-81232009000300020

21. Presidência da República (Brasil). Lei no10.836, de 9 de janeiro de 2004. Cria o Programa Bolsa Família e dá outras providências. Brasília: Diário Oficial da União; 2004 [citado 2018 jun 29]. Disponível em: http://www. planalto.gov.br/ccivil_03/_ato2004-2006/2004/lei/l10.836.htm

22. Ministério do Desenvolvimento Social (Brasil). Relatórios de informações sociais. Brasília: Ministério do Desenvolvimento Social; 2018 [citado 2018 jul 3]. Disponível em: http://aplicacoes.mds.gov.br/sagi

23. Peña CR, Pinheiro DS, Albuquerque PHM, Fernandes LM. A eficácia das transferências de renda: um estudo das tendências e dinâmica da desigualdade antes e depois do Programa Bolsa Família. Rev Adm Pública. 2015;49(4):889-913. http://dx.doi.org/10.1590/0034-7612135532

24. Food and Agriculture Organization. The state of food insecurity in the world: Strengthening the enabling environment for food security and nutrition. Rome: FAO; 2014.

25. Shei A, Costa F, Reis MG, Ko Al. The impact of Brazil's Bolsa Família conditional cash transfer program on children's health care utilization and health outcomes. BMC Int Health Hum Rights. 2014;14:10. http:// dx.doi.org/10.1186/1472-698X-14-10

26. Rasella D, Aquino R, Santos C, Paes-Sousa R, Barreto M. Effect of a conditional cash transfer program me on child hood mortality: A nation wide analysis of Brazilian municipalities. Lancet. 2013;382:57-64. http:// dx.doi.org/10.1371/journal.pntd.0003357

27. Andrade MV, Chein F, Souza LR, Puig-Junoy J. Income transfer policies and the impacts on the immunization of children: The Bolsa Família Program. Cad Saúde Pública. 2012;28(7):1347-58. http://dx.doi.org/10.1590/S0 102-311X2012000700013

28. Pereira Lima L, Oikawa Zangirolani LT. Programa Bolsa Família: perfil, ações intersetoriais e percepção dos gestores de serviços, em um estudo de caso nos Morros de Santos. Demetra. 2016;11(Supl.1):1297-315. http://dx.doi.org/10.12957/demetra.2016.21374

29. Silva ACF, Recine E, Johns P, Gomes FS, Ferraz MA, Faerstein E. History and challenges of Brazilian social movements for the achievement of the right to adequate food. Glob Public Health. 2018;0(0):1-9. http:// dx.doi.org/10.1080/17441692.2018.1439516

30. Conselho Nacional de Segurança Alimentar e Nutricional. Relatório final. II Conferência Nacional de Segurança Alimentar; 17-20 mar, 2004; Olinda, Pernambuco. Olinda: Consea; 2004 [citado 2018 jul 3]. Disponível em: http://bvsms.saude.gov.br/bvs/publicacoes/ll_Conferencia_2versao.pdf

31. Presidência da República (Brasil). Lei n¹1.346, de 15 de setembro de 2006. Cria o Sistema Nacional de Segurança Alimentar e Nutricional - SISAN com vistas em assegurar o direito humano à alimentação adequada e dá outras providências. Brasília: Diário Oficial da União; 2006 [citado 2018 jun 25]. Disponível em: http://www.planalto.gov.br/ccivil_03/_ato2004-2006/2006/lei/l11346.htm

32. Cunha WA, Freitas AF, Salgado RJSF. Efeitos dos programas governamentais de aquisição de alimentos para a agricultura familiar em Espera Feliz, MG. Rev Econ Sociol Rural. 2017;55(3):427-44. http://dx.doi. org/10.1590/1234-56781806-94790550301 
33. Conselho Nacional de Segurança Alimentar e Nutricional. III Conferência Nacional de Segurança Alimentar; 3-6 jul, 2007; Fortaleza. Fortaleza: Consea; 2007 [citado 2018 jul 3]. Disponível em: http://www4.planalto. gov.br/consea/eventos/conferencias/arquivos-de-conferencias/3a-conferencia-nacional-de-segurancaalimentar-e-nutricional/relatorio-final-iii-conferencia-nacional-de-seguranca-alimentar-e-nutricional.pdf

34. Ministério da Saúde (Brasil). Secretaria de Atenção à Saúde. Guia alimentar para a população brasileira: promovendo a alimentação saudável. Brasília: Ministério da Saúde; 2006.

35. Ministério da Saúde (Brasil). Portaria n 154, de 24 de janeiro de 2008.Cria os Núcleos de Apoio à Saúde da Família - NASF. Braślia: Diário Oficial da União; 2008 [citado 2018 jun 25]. Disponível em: http://bvsms. saude.gov.br/bvs/saudelegis/gm/2008/prt0154_24_01_2008.html

36. Vasconcelos IAL, Sousa MF, Santos LMP. Evolução do quantitativo de nutricionistas na Atenção Básica do Brasil: a contribuição dos Núcleos de Apoio à Saúde da Família e da Estratégia Saúde da Família de 2007 a 2013. Rev Nutr. 2015;28(4): 431-50. http://dx.doi.org/10.1590/1415-52732015000400009

37. Presidência da República (Brasil). Lei n¹1.947, de 16 de junho de 2009. Dispõe sobre o atendimento da alimentação escolar e do Programa Dinheiro Direto na Escola aos alunos da educação básica; altera as Leis $\mathrm{n}^{\circ} 10.880$, de 9 de junho de 2004, n¹1.273, de 6 de fevereiro de 2006, $\mathrm{n}^{\circ} 11.507$, de 20 de julho de 2007; revoga dispositivos da Medida Provisória no 2.178-36, de 24 de agosto de 2001, e a Lei n8.913, de 12 de julho de 1994; e dá outras providências. Brasília: Diário Oficial da União; 2009 [citado 2018 Jun 25]. Disponível em: http://www.planalto.gov.br/ccivil_03/_ato2007-2010/2009/lei//11947.htm

38. Ministério da Educação (Brasil). Fundo Nacional de Desenvolvimento da Educação. PNAE: Programa Nacional de Alimentação Escolar. 2017 [citado 2018 jul 28]. Disponível em: http://www.fnde.gov.br/programas/pnae

39. Faleiros VP. A política social do estado capitalista brasileiro. 8a ed. São Paulo: Cortez; 2000.

40. Ruckert INJ, Rabelo MM. O Programa Bolsa Família e os esforços para a redução da pobreza. Indic Econ FEE. 2013;40(4):83-98.

41. Ministério do Desenvolvimento Social e Combate à Fome (Brasil). O Brasil sem miséria. Brasília: Ministério do Desenvolvimento Social; 2014.

42. Ministério do Desenvolvimento Social e Combate à Fome (Brasil). Plano Brasil sem miséria: cadernos de resultados: 2011-2014. Brasília: Ministério do Desenvolvimento Social; 2014 [citado 2018 jul 28]. Disponível em: http://www.mds.gov.br/webarquivos/publicacao/brasil_sem_miseria/cadernodegraficosbsm-35anos.pdf

43. Câmara Interministerial de Segurança Alimentar e Nutricional (Brasil). Plano Nacional de Segurança Alimentar e Nutricional: 2012/2015. Brasília: CAISAN; 2011 [citado 2018 jun 30]. Disponível em: http://www.mds.gov. br/webarquivos/publicacao/seguranca_alimentar/Plano_Caisan.pdf

44. Ministério da Saúde (Brasil). Política nacional de alimentação e nutrição. Brasília: Ministério da Saúde; 2011 [citado 2018 jun 30]. Disponível em: http://bvsms.saude.gov.br/bvs/publicacoes/politica_nacional_ alimentacao_nutricao.pdf

45. Ministério do Desenvolvimento Social e Combate à Fome (Brasil). Marco de referência de educação alimentar e nutricional para as políticas públicas. Brasília: Ministério do Desenvolvimento Social; 2012 [citado 2018 jun 30]. Disponível em: http://acervodigital.mds.gov.br/xmlui/bitstream/handle/123456789/1024/marco_EAN. pdf? sequence $=1$

46. Ministério da Saúde (Brasil). Portaria n¹.920, 5 de setembro de 2013. Institui a estratégia nacional para promoção do aleitamento materno e alimentação complementar saudável no Sistema Único de Saúde (SUS) - Estratégia Amamenta e Alimenta Brasil. Brasília: Diário Oficial da União; 2013 [citado 2018 jun 30]. Disponível em: http://bvsms.saude.gov.br/bvs/saudelegis/gm/2013/prt1920_05_09_2013.html

47. Ministério da Saúde (Brasil). Secretaria de Atenção à Saúde. Guia alimentar para a população brasileira. $2 a$ ed. Brasília: Ministério da Saúde; 2014.

48. Barbosa Filho F. A crise econômica de 2014/2017. Estud Av. 2017;31(89):51-60. http://dx.doi.org/10.1590/s0 103-40142017.31890006

49. Machado C, Lima L, Baptista T. Políticas de saúde no Brasil em tempos contraditórios: caminhos e tropeços na construção de um sistema universal. Cad Saúde Pública. 2017;33(Supl.2). http://dx.doi.org/10.1590/0102-31 $1 \times 00129616$ 
50. Mota LA, Moraes AM. O ajuste fiscal e a crise do novo desenvolvimentismo no segundo mandato de Dilma Rousseff. Rev Café Sociol. 2017;6(2):354-74.

51. Carleial LMF. O projeto de abandono das possibilidades de desenvolvimento do Brasil. IdeAs. 2017;10:1-7. http://dx.doi.org/10.4000/ideas.2222

52. Presidência da República (Brasil). Decreto n8.553, de 3 de novembro de 2015. Institui o pacto nacional para alimentação saudável. Brasília; 2015 [citado 2018 jul 2]. Disponível em: http://www.planalto.gov.br/ ccivil_03/_Ato2015-2018/2015/Decreto/D8553.htm

53. Câmara Interministerial de Segurança Alimentar e Nutricional (Brasil). Plano Nacional de Segurança Alimentar e Nutricional - PLANSAN 2016-2019. Brasília: Ministério do Desenvolvimento Social e Agrário; 2017 [citado 2018 jul 28]. Disponível em: http://www.mds.gov.br/webarquivos/arquivo/seguranca_alimentar/caisan/ plansan_2016_19.pdf

54. Maluf RS, Flexor G. Questões agrárias, agrícolas e rurais: conjunturas e políticas públicas. Rio de Janeiro: E-Papers; 2017.

55. Presidência da República (Brasil). Emenda Constitucional n95, de 15 de dezembro de 2016. Altera o Ato das Disposições Constitucionais Transitórias, para instituir o Novo Regime Fiscal, e dá outras providências. Brasília: Diário Oficial da União; 2016 [citado 2018 jul 2]. Disponível em: http://www.planalto.gov.br/ ccivil_03/constituicao/emendas/emc/emc95.htm

56. Rasella D, Basu S, Hone T, Paes-Sousa R, Ocké-Reis CO. Child morbidity and mortality associated with alternative policy responses to the economic crisis in Brazil: A nationwide microsimulation study. PLoS Med. 2018;15(5):e1002570. http://dx.doi.org/10.1371/journal.pmed.1002570

57. Ministério do Planejamento, Desenvolvimento e Gestão (Brasil). Instituto de Pesquisa Econômica Aplicada. Nota Técnica n²7: o novo regime fiscal e suas implicações para a política de assistência social no Brasil. Brasília: Instituto de Pesquisa Econômica Aplicada; 2016 [citado 2018 jul 28]. Disponível em: http://www. ipea.gov.br/portal/images/stories/PDFs/nota_tecnica/160920_nt_27_disoc.pdf

58. Instituto de Estudos Socioeconômicos. Brasil: direitos humanos em tempos de austeridade. 2017 [citado 2018 jun 13]. Disponível em: http://www.inesc.org.br/noticias/biblioteca/publicacoes/direitos-humanos-emtempos-de-austeridade/view

59. Conselho Nacional de Segurança Alimentar e Nutricional. Documento síntese. Encontro Nacional $5 a$ Conferência +2; 2018 Mar 6-8; Brasília, Distrito Federal. Brasília: Consea; 2018 [citado 2018 jun 26]. Disponível em: http://www4.planalto.gov.br/consea/eventos/conferencias/conferencias-2/encontro-5a-2/ documento-sintese-consea-versao-web.pdf

60. Conselho Nacional de Segurança Alimentar e Nutricional (Brasil). Exposição de Motivos (E.M.) n002-2018/ Consea. Brasília: Consea; 2018. 